\title{
Entrepreneurial Competencies and SMEs Business Success: The Contingent Role of External Integration
}

\author{
Shehnaz Tehseen \\ PhD Candidate, Universiti Kuala Lumpur Business School (UNIKL BIS), BangunanYayasan Selangor, \\ Jalan Raja Muda Abdul Aziz, Kg Baru, 50300 Kuala Lumpur \\ Email: Shehnaz_teh@yahoo.com \\ T. Ramayah \\ School of Management, UniversitiSains Malaysia, Moden 11800 Penang Minden \\ Email: ramayah@usm.my
}

\section{Doi:10.5901/mjss.2015.v6n1p50}

\begin{abstract}
This is a conceptual paper to study the effects of entrepreneurial competencies on success of businesses in the context of Malaysian SMEs. This paper argues that the external integration moderates the influence of entrepreneurial competencies on success of SMEs businesses. Hence, the entrepreneurs should be competent enough to manage their relationships with their customers and suppliers to get competitive advantage. Only sustainable competitive advantage will ensure business survival and success. This paper adopts the resource based view of competencies (RBV) which claims that entrepreneurial competencies are valuable and intangible resources that lead towards the success of business. Entrepreneurial competencies alone are not enough to ensure the survival and success of businesses. Since, SMEs have scarce resources of finance, skills, technology and knowledge; therefore SMEs sustainable business success highly depends on many other factors such as supplier's capabilities as well as customer's integration. Moreover, the strong relationships of SMEs with their customers and suppliers enable them to access the information regarding latest customer choices and tastes, technologies and new methods of innovations. Therefore, this paper incorporates two theories namely, the resource dependence theory (RDT)and the resource based view (RBV) to explain the conceptual model, where RDT suggests that firms have to depend on external parties (suppliers and customers) to get critical resources for their survival. Particularly, there is a dearth of studies that have examined the influence of external integration on the relationship of entrepreneurial competencies and success of Malaysian SMEs businesses. Therefore, the current study strives to investigate the moderating impact of customer and supplier relationships on the relationship between entrepreneurial competencies and success of businesses of Malaysian SMEs in the manufacturing sector. Ultimately, this study will contribute the existing body of knowledge in entrepreneurial competencies, external integration and success of Malaysian SMEs businesses in the manufacturing industry.
\end{abstract}

Keywords: Entrepreneurial competencies; External Integration; Business Success; Manufacturing Industry; Malaysian SMEs

\section{Introduction}

The small and medium-sized enterprises (SMEs) have given much attention in the recent entrepreneurship researches due to their vital contributions in the economy of every country. The appearance of SMEs is very important especially in all developing countries where they assist economic growth; improve income distribution, productivity, efficiency and economic structure during the economic downturn (Abdullah \&Manan, 2011).Small and medium-sized enterprises (SMES) have become more important for the whole world because of their flexible and compatible structures (Kayadibi et al., 2013). These SMEs play a significant role in economies by providing a large portion of production in the rapidly changing world due to their adaptability features. SMEs show major contribution in the development of a county's economy, its political stability as well as social uplifting. SMEs are flexible in nature. They can be established for all kind of activities ofevery business and are considered as a back bone of country's economy (Radamet al.,2008; Amini, 2004). The government has given much attention on the development of SMEs because of their significant role in the economic development (Khalique et al., 2011). 


\subsection{Malaysian SMEs- An Overview}

According to the Census 2011, total 645,136 SMEs businesses were operating in Malaysia which represents $97.3 \%$ of total business establishments. Among them, service sector represented $90 \%$, manufacturing sector constituted $5.9 \%$ and construction sector indicated $3.0 \%$ of the total establishments. On the other hand, only $1.0 \%$ was in agriculture sector and $0.1 \%$ in mining \& quarrying. There were more than 580,000 establishments of SMEs in sector of services which revealed $98.2 \%$ of the total establishments in this sector. While manufacturing sector and construction sector represented $95.4 \%$ and $87.1 \%$ respectively of the total establishments in these sectors. The census 2011 revealed same percentage of micro businesses as compared to the census of 2005. This depicted that the major SMEs were of micro-sized businesses that represented $77.0 \%$, on the other hand, the small businesses and medium-sized establishments represented $20 \%$ and $3.0 \%$ respectively of total establishments of SMEs. The services sector recorded $79.6 \%$, the manufacturing and agriculture sectors represented $57.1 \%$ and $56.3 \%$ respectively of micro-sized establishments. On the other hand, the quarrying and mining sector represented $42.1 \%$ of SMEs that were of small size. According to the findings of the Census 2011, most of the SMEs representing more than 50\% were situated in WP Kuala Lumpur, Selangor, Johor and Perak Meanwhile, SMEs in Sarawak and Sabah represented only 13.1\% of total Malaysian SMEs. The women owned 19.7\% out of 645,136 operating SMEs in Malaysia. The women owned establishments were highest in the services sector that represented $91.7 \%$, followed by in manufacturing sector with $6.9 \%$ but other sectors represented even less than $1.0 \%$. On the other hand, $88 \%$ women were in micro businesses, small businesses represented about $11.3 \%$ and medium size businesses indicated less than $1.0 \%$ women respectively. The SMEs contribution to GDP in Malaysia has increased from $29.4 \%$ in 2005 to $32.7 \%$. During the period between2006 and 2011, SMEs growth was surpassed the overall economic growth. For instance, in the year 2011, SMEs represented the growth of $6.8 \%$ relative to $5.1 \%$ of overall economic growth. In 2012, service sector contributed $61.7 \%$ and manufacturing sector contributed $24.1 \%$ to GDP, on the other hand, the contributions of construction and mining and quarrying sectors to GDP were $2.8 \%$ and $0.2 \%$ respectively. It is evident that SMEs are pivotal for the economic development for all countries. In Malaysia, the development of the SME sector is an extraordinary due to its significant contribution to the growth process of economy over the years (BNM, 2010). Department of Statistics showed in economic census report (2012) that 645,136 Malaysian SMEs were accountable for $97.3 \%$ of total business establishments; whereas, large establishments contributed only $2.7 \%(17,803)$.

The government of Malaysia is focusing more towards the development and growth of SMEs to achieve the vision 2020 of becoming high income nation. The Malaysian government has set targets for SMEs in its master plan for 2020 according to which SMEs are given target to contribute in $41 \%$ in GDP, $62 \%$ in employment and $25 \%$ in exports up to 2020. Up to 2010, SMEs contribution to GDP was only $32 \%, 59 \%$ to employment and $19 \%$ to exports. Thus, in order to get their targets up to 2020, SMEs have to become more competitive in local as well as in international markets. Malaysian government has provided huge financial support to SMEs for their development and growth. And is also assisting in their research and development activities, product development, and production efficiency by establishing various institutions like SMECORP and SME bank etc(Ahmad \&Seet, 2009; Central Bank of Malaysia, 2006).

\subsection{Definition of SMEs}

Table 1 show the new definition of SMEs by size of operation which was implemented since Jan 2014.

Table 1: Definition by Size of Operation

\begin{tabular}{|l|l|l|l|}
\hline Category & Micro & Small & Medium \\
\hline Manufacturing & $\begin{array}{l}\text { Sales turnover of less than } \\
\text { RM300,000 } \\
\text { OR } \\
\text { Employees of less than 5ales turnover from RM300,000 to } 5\end{array}$ & $\begin{array}{l}\text { Sales turnover from RM15 million to not } \\
\text { exceeding RM50 million } \\
\text { less than RM15 million } \\
\text { OR } \\
\text { OR } \\
\text { full-time employees from 5 to less } \\
\text { than 75 }\end{array}$ & $\begin{array}{l}\text { full-time employees from 75 to not exceeding } \\
200\end{array}$ \\
\hline $\begin{array}{l}\text { Service and other } \\
\text { sectors }\end{array}$ & $\begin{array}{l}\text { Sales turnover of less than } \\
\text { RM300,000 } \\
\text { OR } \\
\text { Employees of less than 5ales turnover from RM300,000 to } 5\end{array}$ & $\begin{array}{l}\text { Sales turnover from RM3 million to not } \\
\text { exceeding RM20 million } \\
\text { less than RM3 million } \\
\text { OR } \\
\text { full-time employees from 5 to less } \\
\text { than 30 }\end{array}$ & $\begin{array}{l}\text { full-time employees from 30 to not exceeding } \\
75\end{array}$ \\
\hline
\end{tabular}

Source: SEM Corp, 2013 


\subsubsection{Classification of Sectors}

According to SEM Corporation (2013), the above sectors can be classified as follows:

Manufacturing represent chemical or physical transformation of components or materials into new products.

Services indicate all services including hotels and restaurants; distributive trade; private education and health; professional and ICT services; entertainment; financial intermediation; and manufacturing-related services such as R\&D, warehouse etc.

Others represent the following three remaining key economic activities, namely:

(i) Primary Agriculture which includes Livestock, Cash crops and Perennial crops, Forestry \& logging, Aquaculture and Marine fishing.

(ii) Construction which constitutes Special trade, Residential \& non-residential and infrastructure.

(iii) Mining \& quarrying

\subsection{Importance of Manufacturing Sector for Malaysian Economy}

Malaysian manufacturing sector is ranked in the 23rd position among the world countries. According to Wikipedia report, Malaysia is considered as one of the largest exporters of semiconductor devices and components, solar panels, electrical goods and ICT products in the world. The Malaysian electrical and electronics (E\&E) industry is accountable for $26 \%$ of manufacturing output and is considered as the largest single contributor to the manufacturing sector. These manufacturing industries highly contribute in Malaysian economy. The major Malaysian manufacturing industries are related with food processing, furniture and electronics.

The Malaysian manufacturing sector creates demand for fast productivity growth service sub-sectors which include finance, transportation and telecommunications. Apart from this, the manufacturing sector also provides a platform for spins-offs in production services such as design consultancies and engineering with its production and processes. The comparative advantage in Malaysian manufacturing sector results into situation of healthy balance of payments and leads towards standards of living as well.

According to Malaysian Industrial Development Authority (MIDA), the data revealed that the manufacturing sector is attracting more foreign direct investment (FDI) in this sector as compared to service sector. In 2011, FDI increased by $12.3 \%$ to around RM33.7 billion, and this sector's total share was around RM16.85 billion in FDI. Also in the year 2011, the total investments in the Malaysian sector also increased, 846 manufacturing projects of total value RM56.9 billion started in the year 2011 were approved which was $19 \%$ more than the RM47.8 billion recorded in 2010 . This indicates the importance of the manufacturing sector in the growth of Malaysian economy.

This is the major sector in Malaysian economy that generates employment opportunities. Manufacturing sector contributes $80 \%$ of overall country's export. Malaysia is ranked 17 th as the largest exporting country in the world.

\subsection{Problems Faced by Manufacturing Sector}

Manufacturing sector produces wealth for any country and impacts a lot on the country's economy. Malaysia is middle income country and its economy largely depends on service and manufacturing sectors. Thus, there is a big challenge to be a leader in high value added sector of manufacturing in order to achieve vision 2020 of becoming a high income nation.

In order to achieve the status of a high-income and of an advanced economy, Malaysia has to grow at $6 \%$ per annum according to the Tenth Plan period. The manufacturing sector contributes $20.6 \%$ to its GDP. This sector will be a major economic growth driver during the Tenth Malaysia Plan period (2011 to 2015). According to Tenth Malaysia Plan, this sector is expected to grow at $5.7 \%$ annually until completion of this plan period by contributing $26.3 \%$ to GDP. This growth will largely depend on improving the productivity of sector.

The Malaysian SMEs are facing various challenges and issues such as insufficient skilled labour force that resulted low productivity and low quality output, competition from global market especially from producers of China and India, low capability to meet the requirements of globalization standards and lack of management skills and expertise.

In Malaysia, the manufacturing sector has a problem in maintaining its quality, competitiveness, and Just-In-Time delivery of the products. These three requirements are crucial to gain market share. The manufacturing sector is an industry that is driven by knowledge and technology. Also Malaysia produces and promotes high-tech products and services. Thus, it is not easy to remain competitive with current market conditions where the technology is rapidly changing and developing. Besides the rapidly changing technological products, manufacturing sector is lacking of 
technical and marketing skills as well. Moreover, the manufacturing sector in Malaysia also lacks of the utilization of ICT in production processes that impact a lot on its productivity as ICT is a vital tool that closes the gap between the existing and latest technology such as grid computing, nano-technology, RFID and WIFI. Their utilization is very crucial to gain competitiveness and high productivity. Thus, in order to solve various issues and problems faced by the Malaysian manufacturing sector, this paper argues that the entrepreneurial competencies leads towards the success of SMEs business in the Malaysian manufacturing sector. And the external integration (customer relationship and supplier relationship) moderates the influence of the entrepreneurial competencies on success of SMEs businesses. The detail of the competencies and external integration are discussed next.

\section{Literature Review}

This section will highlight the review of important studies relevant to entrepreneurial competencies, business success, external and internal integration, RBV (Resource Based View) and RDT (Resource Dependency Theory).

\subsection{Entrepreneur and Entrepreneurial Competencies}

The literature of entrepreneurship has highlighted the role of entrepreneurs for the business success of SMEs. An entrepreneur is an individual who develops and grows the businesses through creative and innovative activities, by introducing new products or services, by improving the existing methods of production or service. Thus, the competencies of entrepreneurs make a business more successful and may lead towards its sustainable competitive advantage as well. Entrepreneurial competencies are related with the performance of the firm and its competitiveness (Man et al., 2002), growth and success of business (Colombo \&Grilli, 2005). According to many studies, the entrepreneur's psychological and behavioural, demographic characteristics, managerial and technical skills are the most important determinants for the performance and success or failure of small and medium sized enterprises (Rasmussen et al., 2011; Man, Lau, \& Snape, 2008; Man, Lau, \& Chan, 2002; Chandler \& Hanks, 1994).It is very essential to understand entrepreneurs in the context of emerging economies because the entrepreneurial competencies for business growth and survival in emerging economies are different from those of in developed economies (Solesvik, 2012). Also Capaldo et al (2004) stated that the entrepreneurial competencies vary according to different contexts. Thus, this paper argues that in the context of Malaysia, the external integration plays a vital role and improves the relationships of entrepreneurial competencies and business success.

External integration is the predominant feature of supply chain integration across every kind of businesses. External integration represents customer and supplier integration which concentrate on development of intense relationships of the businesses with their customers and suppliers. Firms integrate with their customers and suppliers through collaborative relationships and information sharing processes (Stevens, 1989). The external integration constitutes three fold dimensions such as integration of information, costs and gains; organizational and coordination linkages for sharing risks (Lee,2000). Supplier integration is seen as the most common practice of supply chain integration (Fawcett \& Magnan, 2002). It refers to the firm's interaction with their suppliers for effective alignment and participation as well as for the sharing of valuable information(Ragatz et al., 2002). The supplier integration also constitutes the coordination between firm's core competencies and its key suppliers that are critical for its business (Bowers ox et al., 1999). On the other hand, the customer integration refers to the immediate responses to meet customer's needs and requirements (Boon-itt \& Pongpanarat, 2011). Therefore, for the success of SMEs businesses, the role of external integration is pivotal as they can provide valuable information regarding trends of products or services and customer's tastes as well as their demands to the firms in the competitive markets. Thus, the entrepreneurs must be competitive enough to develop successful relationships with their suppliers and customers. Only than the sustainable competitive advantage can be achieved which will ensure the long term success of SMEs businesses.

\subsection{Resource- Based View (RBV) and Entrepreneurial Competencies}

Firm's Resource Based View (RBV) suggests that a firm can distinguish itself from its competitors and can create sustainable competitive advantage only if it possess valuable, rare, and inimitable resources (Barney, 1991). The theorists of RBV have observed that entrepreneur's competencies are key a resource of the firms that are valuable as well. Human capital is an intangible asset of firms that enables them to be more successful. The valuable skills, knowledge and abilities of an entrepreneur may lead to sustainable competitive advantage of firm because entrepreneurial competencies are usually very rare and difficult for rivals to develop all essential competencies. Only the competent entrepreneurs may 
develop and lead successful strategies towards the success of businesses. For instance, the firm's RBV theory relates its value creation process to the manager's capability in finding or developing resources (Grant, 1991; Barney, 1991).

The concept of entrepreneurial competency is used in the literatures of competency, competence and entrepreneurship. Although the term entrepreneurship is often linked with creation of new ventures and management of small businesses (Gibb, 1996) but all the small businesses are not entrepreneurial, nor all owner managers be entrepreneurs. It is vital to understand the meanings of entrepreneur in order to explore entrepreneurial competencies. Early researchers used to identify entrepreneurs through their traits and characteristics. However, the researchers could identify all traits and characteristics only in a few entrepreneurs that were described in the literature. The entrepreneurs with different clusters of traits depend on type of their personality. The entrepreneurship research focuses more on theories of competencies because of limitations of trait approaches. Entrepreneurial competencies are possessed by individuals who are the entrepreneur's means who start organizations and then add value through resource organization and opportunities (Bird, 1995). She stated that the competencies are essential to start a new venture but successful entrepreneurs are those who survive and grow their businesses through their competencies. The competencies are learnable; therefore it is crucial to recognize the importance of competencies. Bird (1995) referred entrepreneurial competencies to the underlying characteristics such as traits, self-images, specific knowledge, motives, social roles and skills that lead to venture birth, survival its growth. Whereas Man et al. (2002) defined them as the entrepreneur's ability to successfully perform a job role. Thus, there is a general consensus that the competencies of entrepreneurs are possessed by those individuals who start and further develop their businesses. Johnson and Winterton (1999) observed that small businesses require skills and entrepreneurial competencies that are very much different than from larger organizations. The main aspect of competency literature is to search for all those individual characteristics that contribute towards the success of an organization. These characteristics of individuals can vary due to their different motives, traits, social roles and skills (Boyatzis, 1982). Stuart \& Lindsay (1997) referred competencies with a person's characteristics, skills and knowledge. Most researchers recognized the difference between entrepreneurial competencies and managerial competencies, as different entrepreneurial competencies are needed to start a new venture than those who manage the growth of an existing business (Man et al., 2002; Chandler \& Hanks, 1994; Chandler \& Jansen, 1992).

\subsection{The Concept of Business Success in SMEs}

The goal of every business is to be successful and success is defined in various different ways. But the literature showed inconsistencies of what constitutes measure of success. Some researchers focused on use of financial indicators while others considered non-financial indicators of success. The former asserted on traditional financial measures of performance such as turnover of sales, profitability, return on investment to predict the success and failure of a firm (Bruderl \& Preisendorfer, 1998). The researchers who prefer financial measures of success usually argued that for the success of the organizations, it is vital to generate profits and to show some level of growth which is represented by volume of their sales (Perren, 2000). Wiklund (1999) suggested that both aspects of performances i.e financial and nonfinancial complement each other and indicate the actual performance of business. Thus, it is not sufficient to focus only on financial performance while neglecting the other measures that indicate the business success as well (Buttner\& Moore, 1997). Murphy et al. (1996) argued that both the financial and non-financial dimensions of organizational performance are needed to be emphasized in the future studies to capture total organizational performance. Thus, this paper also includes both financial as well as non-financial indicators of SMEs business success in its proposed conceptual model.

\subsection{Entrepreneurial Competencies and Business Success}

The entrepreneurial competencies are associated with birth, survival and venture's growth (Colombo \& Grilli, 2005; Baum et al., 2001; Bird, 1995). It is evident that an entrepreneurial skills result into venture performance, profitability and its growth (Lerner \& Almor, 2002; Bird, 1995; Cooper et al., 1994; Chandler \& Jansen, 1992). According to Mitchelmore \& Rowley (2010), the literature emphasizes different approaches to reveal the impact of competencies on performance. For instance, the entrepreneurs seek for better opportunities for their ventures. And management competencies of entrepreneurs are related to formulate venture strategy that better fit with their businesses. Bird (1995) referred competency to the quality of entrepreneur's action that contributes to venture outcomes. Chandler \&Jansen (1992) clustered the entrepreneur's competencies identified through the literature according to three basic roles such as technical skills, entrepreneurial skills and managerial role. They found that entrepreneur's competencies were related with venture performance. Freel (1999) noted that various deficiencies of management such as poor planning, insufficient 
marketing, insufficient functional expertise, inadequate delegation, and discontinuity of management staff within small firms were related to the failure of small businesses. Personal qualities, self-confidence, leadership, innovativeness and risk-taking abilities are very essential for entrepreneur success (Martin \&Staines, 1994). Man et al. (2002) indicated ten areas of competencies of entrepreneurs which are innovative, learning, opportunity, analytical, human, relationship, commitment, strategic, operational and personal competencies. Such competencies show both direct and indirect influence on performance of SMEs. Entrepreneur's skills keep on changing as the firm enters from one development stage to another (Lewis \&Churchill, 1983). Thus, it is vital to understand the changes that result from venture's growth because entrepreneur's skills and capabilities for one stage will be not suitable for another (Mitchelmore, \& Rowley, 2010).

\subsection{Domain of Entrepreneur Competency}

The entrepreneurs have to perform various tasks that may be more complex than that of managers of the organization because of their engagement in various functional, managerial and entrepreneurial duties. Such tasks are multitudinous and can be best achieved via right behaviours (Mole et al., 1993).Such behaviours constitutes the components of individual characteristics such as beliefs, motives, social role, knowledge, self-image, skills and traits (Bird, 1995) that impacts on the ability of the entrepreneurs to perform the activities of business in most effective manner. It's essential to understand the detail of each competency area in order to understand the associated behaviours with each competency area.

\subsubsection{Strategic Competency}

According to Man, Lau \& Chan (2002) this competency is related with the establishing, evaluating and executing the strategies for the firm. Man (2001) operationalised this area of competency by measuring the following behaviours: (1) knowing clearly the expected directions and the impact of changes on firm's performance (2) giving priority to work that aligns the business goals only (3) redesigning the firm to achieve the goal in a better way (4) linking or associating the current actions with strategic goals (5) observing progress towards strategic goals (6)analyzing results against strategic goals (7) establishing strategic actions by assessing cost and benefit (Man, 2001). Thompson \& Richardson (1996) suggested managing change as a component of strategic competence that can be associated with competitive success of all those firms operating in highly competitive environment.

\subsubsection{Conceptual Competency}

According to Man et al. (2002) this area involves different conceptual abilities that the entrepreneurs reflect in their behaviours. Such as innovativeness, risk taking, decision skills, observing and understanding complex information. Whereas according to Chandler \&Jansen (1992) this competency reflects the mental capability to coordinate all the activities of the business. Man (2001) operationalised this area of competency by measuring the following behaviours: (1) taking suitable risk related with job (2) understanding the understanding of the observations and issues (3) translating the ideas and observation of business into the context of business (4) monitoring progress towards the achievement of objectives in risky actions (5) exploring new ideas (6) looking problems in new ways (7) and treating the new problems as opportunities. Man (2001) identified that through factorial analysis this area of competency can be divided into innovative and analytical domains. In this study these two components have been aggregated in to conceptual competency that reflects the initial model of Man (2001).

\subsubsection{Opportunity Competency}

According to Man et al. (2002) this competency refers to the ability to recognize the opportunities in the market through various means. And is operationalized by measuring various behaviours such as identifying the services or products needed by the customers, perceiving unmet needs of the customers, looking for beneficial product and services for the customers, and availing the best opportunities. De koning (2003) linked the opportunity development with the entrepreneur's ability to seek, explore, develop and assess better existing opportunities in markets. One of the main characteristics of entrepreneur is that they can see or recognize the opportunities where others cannot do so (Allison, Chell, \&Hayes, 2000). 


\subsubsection{Learning Competency}

This competency indicates the ability of the entrepreneurs to learn from various ways and means, keep themselves up to date in the relevant field, learn proactively, and then apply learned knowledge and skills into practical activities (Man, 2001). In the new modern social era the new knowledge is created and disseminated rapidly thus, the entrepreneurs require the learning competency to meet the demands of changing environment (Deakins \& Freel, 1998). Learning is critical for entrepreneurial process because it helps the entrepreneurs to generate the knowledge and reduce risks and uncertainty (Ward, 2004). Stokes \&Blackburn (2002) conducted a study regarding business failure experiences of the business owners and revealed that their three-quarters of the respondents had improved skills in the areas of personal management after experiencing business closure.

\subsubsection{Personal Competency}

According to Man (2001), this competency represents the ability to motivate self for performing performance at an optimum level while maintaining a high level of energy, ability to respond to criticism, maintain a positive attitude, identify strengths and weaknesses and match them with the threats and opportunities, and recognize own short comings and work on their improvements. This area of competency has been linked with the success of entrepreneurs. The literature discusses various aspects of personality and attitude that are included in this competency. For instance, it may include self-belief and determination (Thompson et al., 1997), stress tolerance and self-control (Markman\& Baron, 1998). Thus, the owner's personal strength is considered as one of the key business resources and the success depends on the utilization of this skill (Ahmad, 2007).

\subsubsection{Ethical Competency}

Ormeand Ashton (2003) advocated that ethics is an important part of a competency framework and is a backbone of corporate life as well. According to Ahmad (2007), this competency represents the ability of honesty and transparency in business dealings by admitting mistakes and telling the truth. An entrepreneur with ethical competency offers services or products at fair prices and takes responsibility for own actions. An individual behaves ethically when her or his actions ensure that these rules and practices are applied in all business situations in a consistent way (Orme \& Ashton, 2003).Moreover, ethical practices are concerned more in modern businesses because there is a growing awareness that such ethical practices will give good return in long run of business (Zairi\& Peter, 2002). It is believed that good ethics is in benefit for business because of which there is an increase interest behaving ethically in businesses (Spence \& Rutherfoord, 2001). Also the good ethical behaviour which a company portrays to public may impact on its reputation and image (Jones, 2001).

\subsubsection{Familism}

Familism refers to such social norms that manage the relationships within family and among other members (Zuanna, 2001). Familism is a form of social organization of obligations and role rights that links kin members to one another and is related with communalism because of individual's commitment and loyalty towards his or her own group (Ho et al., 2014). Ahmad (2007) identified in her study that the behaviours of Malaysian entrepreneurs reflect familism. And found that the Malaysian entrepreneurs identified their close associates and family as being critical for their business success. Her study indicated that the Malaysian entrepreneurs give more importance in receiving support and advice from members of their family, sharing resources and knowledge with close associates to overcome obstacles in managing their businesses and also identify and seek help from their trusted employees. Thus, familism assists the firm to develop a community of trust within business network as well as within its internal structure (Wijaya, 2008).

\subsection{Resource Dependence Theory (RDT) and External integration}

The resource dependence theory concentrates on the needs of firm's resources. Hence, to gain required assets the firms seek to build relationships with other firms (Nohria\& Garcia-Pont, 1991; Kogut, 1988; Salancik \& Pfeffer, 1978). Thus, RDT is concerned with firm's requirements to gain resources from other actors in its environment and states how scarcities of firm's resources force it to introduce new innovations that utilize alternative resources (Sherer\& Lee 2002; Salancik \& Pfeffer, 1978).In other words, the SMEs have to depend on their suppliers as well as customers in order to get 
needed resources such as quality raw material, technology, emerging trends and information regarding current tastes and demands of customers. Thus, based on RDT, this paper argues that the SMEs have to develop and maintain long term relationships with their suppliers and customers to achieve the required resources which are critical for their survival and success.

Integration means the extent to which different parties collaborate and work together in a cooperative manner to achieve mutual outcomes (Richey et al, 2009). External integration means the extent to which a firm can build or develop relationships with its suppliers and customers to structure its behaviours, organizational strategies, procedures, and practices into collaborative processes to meet the customer needs (Chen \& Paulraj, 2004; Stank et al., 2001b). External integration of a firm constitutes the strategic alliance with its customers and suppliers to build strategic partnerships with them to develop strategies for availing market opportunities (Narasimhan \& Kim, 2002). Synchronized planning, information sharing and working collaboratively with customers and suppliers are important themes of external integration to facilitate operations and solve business problems (Zhao et al., 2011). External integration helps companies to reduce transaction costs by developing collaborative relationships with external parties (Zhao et al., 2008). External integration has been used as a moderator in very few studies. For instance, Zahra \& Nielsen (1998) used external integration as a moderator between manufacturing capabilities and technology commercialization. The literature highlights the positive association between integration and firm's performance (Rodrigues et al., 2004; Frohlich \& Westbrook, 2001; Stank et al., 2001). External integration indicates the higher level of supply chain management and is positively related to business operational performance (Flynn et al., 2010; Stevens, 1990, 1989).The interactions with outside parties have helped organisations to gain super business performance by giving immediate responses to the needs of customers (Frohlich \& Westbrook, 2001). Also external integration leads to higher level of operational competency where by the products can be easily available to customers to meet their demands through distribution networks (Halley \&Beaulieu, 2009).Koh et al (2007) found the positive impact of strategic relationships of Turkish SMEs with their customers and suppliers on their business performances. Organizational performance can be measured by using both criteria of financial and non-financial performances. Although for every business the financial performance is the ultimate goal but external integration impacts on other indicators such as innovation performance of SMEs as well (Llorens et al., 2003), non-financial performance and market share (Demirbag et al., 2006). The external integration enhances productivity and increases market share of SMEs businesses (Li et al., 2006; Lyons et al., 2004; Tan et al., 1998). Thus, based on available literature that provide evidence regarding importance of external integration for firm's success, this paper argues that external integration plays a role of moderator in the relationships between entrepreneurial competencies and business success. In other words, it would be better to say that the entrepreneurs must be enough competent to manage the relationships with their external parties to get access to the critical and scare resources. Thus, such management of relationships with external parties enables them to gain vital resources for the survival and superior success of their businesses.

\subsection{Supplier Relationship}

Supplier relationship which is also known as vertical integration refers to building and developing strategic firm's relationships with its suppliers (Li et al., 2005). Through collaborative relationships with the suppliers the firms acquire components and raw materials for their manufacturing processes. Koh et al. (2007) stated that supplier relationship includes the collaboration and coordination between supplier and buyer. The strategic partnerships involve suppliers in many important activities such as procurement, research and development, distribution and decision-making (Bagchi et al., 2005). The manufacturing firms can minimize purchased lead-time, share information and develop multi-skilled workforce training by building strategic alliances with suppliers (Koh et al., 2007). Also such collaborative relationships with suppliers provide many other benefits such as stimulation of new ideas, mutual problem solving, improvement in product and process, transfer of technology, design refinement, less waste and lower costs, higher quality and innovation (Jones, 1996).

SMEs have lack of financial resources, technology, skills and knowledge (Hashim, 2007); therefore, their business success and its stability highly depend on more co-operative relationships and capabilities of its suppliers (Morrisey \& Pittaway, 2006; Mudambi et al., 2004) Park \& Krishnan, 2001; Jones, 1996;Mudambi\&Schrunder, 1996). The close relationships with suppliers actually compliment the scarcity of SMEs' resources and help SMEs to access to the new innovation ways, process, technologies and materials (Pressey et al., 2009; Koh et al., 2007). Small companies utilize supplier relationships to improve their innovations in production process and designs, reduce supply shortage risk and meet unexpected high customer demands by developing external and internal capabilities and expertise (Fawcett et al., 2008; Ellegaard, 2006); Jones, 1996, ; Lipparini \& Sobrero, 1994). 


\subsection{Customer Relationship}

In literature the customer relationships has been conceptualized in many ways such as developing relationships (loyalty), maintaining relationships (interaction) and creating relationships (attraction) (Izquierdo et al.,2005). SMEs usually have fewer customers or relatively small customer base (Thakkar et al., 2009), thus, customer relationships is pivotal and is one ofthe critical success factors of SMEs business success (Meehan \& Muir,2008). Indeed, most of the SMEs have only few major or stronger customers who have more demands (John Morrisey \& Pittaway, 2006). Therefore, SMEs develop more closer, personal and long term relationships with their customers (Bhutta et al. 2007; Hong \& Jeong, 2006). Min and Mentzer (2004) suggested that close and good customer relationship is essential for understanding and fulfilling their needs. The customer's satisfaction results in their loyalty and thus contributes a lot towards firm's success (Mentzer, 2001).

\section{Conceptual Model}

The Figure 1 depicts the hypothesized model that links the entrepreneurial competencies, external integration and business success. The proposed theoretical construct of entrepreneurial competencies refers to familism, ethical, learning, personal, conceptual, opportunity and strategic competencies (which were found specific in the Malaysian context by Ahmad (2007). The external integration includes customer relationship and supplier relationship. And business success constitutes both financial and non-financial performances of the firm. Also it should be noted that the proposed constructs are not complete set of measurement scale for other contexts as all the dimensions of entrepreneurial competencies and supply chain integration practices cannot be included in a single study.

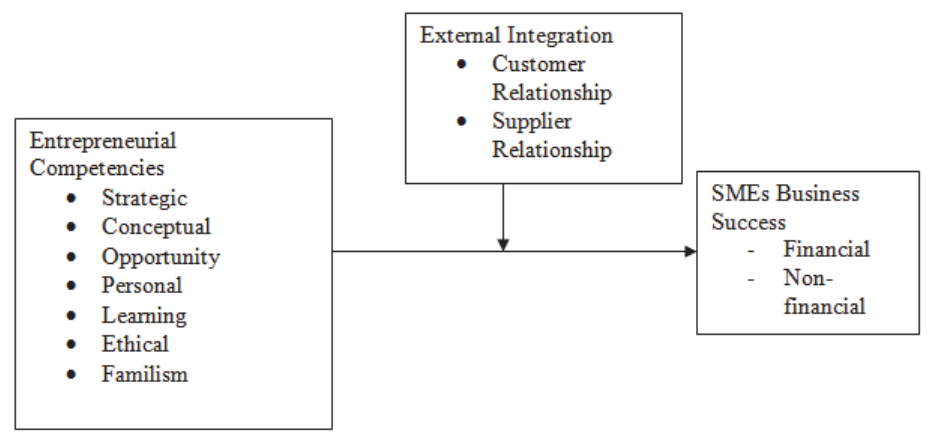

Fig 1. Proposed conceptual model

\section{Conclusion}

This paper has described the conceptual framework regarding the importance of entrepreneurial competencies towards the business success of SMEs by incorporating the concept of external integration as a moderator between the relationships of the independent and dependent variables. As the existing literature reveals the importance of entrepreneurial competencies towards business success, this paper thus argues that through external integration, this relationship can be more improved. But this is just a conceptual paper; it suggests that an empirical study should be conducted in future by using this conceptual framework to see the impact of external integration as a moderator between the entrepreneurial competencies and business success.

\section{References}

Abdullah, M. A., Manan, S. K. A., (2011). Small and Medium Enterprises and Their Financing Patterns: Evidence from Malaysia. Journal of Economic Cooperation and Development, 32(2), 1-18.

Allinson, C.W., Chell, E., \& Hayes, J. (2000).Intuition and entrepreneurial behaviour. European Journal of Work and Organizational Psychology, 9(1), 31-43.

Ahmad N. (2007). A cross-cultural study of entrepreneurial competencies and entrepreneurial success in SMEs in Australia and Malaysia, Unpublished doctoral thesis, University of Adelaide.

Amini, A. (2004). The distributional role of small business in development. International Journal of Social Economics, 31(4), 370-383. 
Ahmad, N. H., \&Seet, P. S. (2009). Dissecting behaviours associated with business failure: a qualitative study of SME owners in Malaysia and Australia. Asian Social Science, 5(9), 98-104.

Barney, J. (1991). Firm resources and sustained competitive advantage. Journal of management, 17(1), 99-120.

Bartlett, A., \& Preston, D. (2000). Can ethical behaviour really exist in business. Journal of Business Ethics, 23(2), $199-209$.

Bagchi, P. K., Ha, B. C., Skjoett-Larsen, T., \& Soerensen, L. B. (2005). Supply chain integration: A European survey. International Journal of Logistics Management, 16(2), 275-294.

Bowersox, D., Closs, D. J., \& Stank, T. P. (1999). 21st century logistics: Making supply Chain integration a reality. Oak Brook, IL: Council of Logistics Management.

Boyatzis, R.E (1982). The Competent Manager: A Model for Effective Performance. New York: Willey.

Buttner, E. H., \& Moore, D. P. (1997). Women entrepreneurs: moving beyond the glass ceiling. Thousand Oaks, CA: Sage Publications Inc, 8, 11-37.

Brüderl, J., \&Preisendörfer, P. (1998).Network support and the success of newly founded business. Small business economics, 10(3), 213-225.

Baum, J. R., Locke, E. A., \& Smith, K. G. (2001).A multidimensional model of venture growth.Academy of management journal, 44(2), 292-303.

Bird, B. (1995).Toward a theory of entrepreneurial competency. Advances in Entrepreneurship, Firm Emergence, and Growth, JAI Press, 2, 51-72.

Boon-itt, S., \&Pongpanarat, C. (2011). Measuring service supply chain management processes: The application of the Q-sort technique. International Journal of Innovation, Management and Technology, 2(3), 217-221.

Bhutta, M. K. S., Rana, A. I., \&Asad, U. (2007).SCM practices and the health of the SMEs in Pakistan.Supply Chain Management: An International Journal, 12(6), 412-422.

Colombo, M. G., \&Grilli, L. (2005). Founders' human capital and the growth of new technology-based firms: A competence-based view. Research policy, 34(6), 795-816.

Cooper, A. C., Gimeno-Gascon, F. J., \& Woo, C. Y. (1994). Initial human and financial capital as predictors of new venture performance.Journal of business venturing, 9(5), 371-395.

Chen, I. J., \&Paulraj, A. (2004). Towards a theory of supply chain management: the constructs and measurements. Journal of operations management, 22(2), 119-150.

Central Bank of Malaysia, 2006.Small and Medium Enterprise (SME) Annual Report 2005. Retrieved June 26, 2014 from http://www.bnm.gov.my/index.php?ch=en_press\&pg=en_press_all\&ac=1279\&lang=en

Chandler, G. N., \& Hanks, S. H. (1994). Market attractiveness, resource-based capabilities, venture strategies, and venture performance. Journal of business venturing, 9(4), 331-349.

Chandler, G. N., \& Jansen, E. (1992). The founder's self-assessed competence and venture performance. Journal of Business venturing, 7(3), 223-236.

Capaldoa, G., Iandolib, L., \&Ponsiglionec, C.(2004) Entrepreneurial competencies and training needs of small firms: A methodological approach,. Paper presented at the 14th Annual IntEnt Conference, Napoli.

De Koning, A. (2003). Opportunity development: A socio-cognitive perspective. Advances in entrepreneurship, firm emergence and growth, 6, 265-314.

Deakins, D., \&Freel, M. (1998). Entrepreneurial learning and the growth process in SMEs. Learning Organization, The, 5(3), $144-155$.

DallaZuanna G. (2001). The banquet of Aeolus. A familistic interpretation of Italy's lowest low fertility. Demographic Research, 4(5), 133162.

Demirbag, M., Koh, S.C.L., Tatoglu, E. and Zaim, S. (2006). TQM and market orientation's impact on SMEs' performance. Industrial Management \& Data Systems, 106 (8),1206-28.

Ellegaard, C. (2006). Small company purchasing: A research agenda. Journal of Purchasing \& Supply Management, 12, $272-283$.

Fawcett, S. E., \&Magnan, G. M. (2002). The rhetoric and reality of supply chain integration. International Journal of Physical Distribution \& Logistics Management, 32(5), 339-361.

Freel, M. S. (1999). Where are the skills gaps in innovative small firms?.International Journal of Entrepreneurial Behaviour\& Research, 5(3), 144-154.

Flynn, B.B., Huo, B., Zhao, X., 2010. The impact of supply chain integration on performance:a contingency and configuration approach. Journal of Operations Management 28 (1), 58-71.

Frohlich, M. T., \& Westbrook, R. (2001). Arc of integration: An international study of supply chain strategies. Journal of Operations Management, 19, 185-200.

Fawcett, S. E., Magnan, G. M., \&Mccarter, M. W. (2008). Benefits, barriers, and bridges to effective supply chain management. Supply Chain Management: An International Journal, 13(1), 35-48.

Grant, R. M. (1991). The resource-based theory of competitive advantage: implications for strategy formulation. Knowledge and Strategy.(Ed. M. Zack), 3-23.

Gibb, A. A. (1996). Entrepreneurship and Small Business Management: Can We Afford to Neglect Them in the Twenty-first Century Business School? British Journal of Management, 7(4), 309-321.

Ho, T. C. F., Ahmad, N. H., \&Thurasamy, R. (2014). Learn and thou shall thrive: Advancing a model of workplace familism and organizational learning capability in small and medium enterprise (SMEs) manufacturers in Malaysia.Business Strategy Series, 14(5/6), 4-4. 
Halley, A., \& Beaulieu, M. (2009).Mastery of operational competencies in the context of supply chain management. Supply Chain Management: An International Journal, 14(1), 49-63.

Hong, P., \&Jeong, J. (2006). Supply chain management practices of SMEs: From a business growth perspective. Journal of Enterprise Information Management, 19(3), 292-302.

Hashim, M. K. (2007). SMEs in Malaysia: A brief handbook. Malaysia: August Publishing Sdn. Bhd.

Izquierdo, C. C., Cillan, J. G., \& Gutierrez, S. S. M. (2005). The impact of customer relationship marketing on the firm performance: A Spanish case. Journal of Services Marketing, 19(4), 234-244.

Johnson, S. and Winterton, J. (1999).Management skills. Skills Task Force research paper, 3,Department for Education and Employment, Nottingham.

Jones, R. (1996). Small-firm success and supplier relations in the Australian boat-building industry: A contrast of two regions. Journal of Small Business Management, 34(2), 71-78.

Jones, J. (2001). Ethics revisited. The 1990s: an ethical decade or a decade of hypocrisy? 15 Retrieved June 26, 2014 from http://commerce.flinders.edu.au/researchpapers/00-6.htm

John Morrissey, W., \&Pittaway, L. (2006). Buyer-supplier relationships in small firms: The use of social factors to manage relationships. International Small Business Journal, 24(3), 272-298.

Kayadibi, S., Polat, R., \&Fidan, Y. (2013). Small and Medium-Sized Business in Malaysian Economy: Case of Turkish Entrepreneurs in Kuala Lumpur. Business Economy, 31, 265-281.

Kogut, B. (1988). Joint ventures: theoretical and empirical perspectives. Strategic Management Journal, 9 (4), 319-32.

Khalique, M., Isa, A. H. B. M., Shaari, N., Abdul, J., \&Ageel, A. (2011). Challenges Faced by the Small and Medium Enterprises (SMEs) in Malaysia: An Intellectual Capital Perspective. International Journal of Current Research, 3(6), 398-401.

Koh, S. L., Demirbag, M., Bayraktar, E., Tatoglu, E., \&Zaim, S. (2007). The impact of supply chain management practices on performance of SMEs. Industrial Management \& Data Systems, 107(1), 103-124.

Kogut, B. (1988). Joint ventures: Theoretical and empirical perspectives. Strategic management journal, 9(4), 319-332.

Llorens, F.J., Ruiz, A. and Molina, L.M. (2003). An analysis of the relationship between quality and perceived innovation: the case of financial firms. Industrial Management \& Data Systems, 103, 579-90.

Lee, H. L. (2000). Creating value through supply chain integration. Supply chain management review, 4(4), 30-36.

Lerner, M., \&Almor, T. (2002).Relationships among strategic capabilities and the performance of women-owned small ventures. Journal of Small Business Management, 40(2), 109-125.

Lewis, V. L., \& Churchill, N. C. (1983). The five stages of small business growth. Harvard business review, 61(3), 30-50.

Li, S., Ragu-Nathan, B., Ragu-Nathan, T.S. \& Rao, S.S. (2006). The impact of supply chain management practices on competitive advantage and organizational performance. Omega, 32, 107-24.

Lyons, A., Coleman, J., Kehoe, D. \& Coronado, A. (2004). Performance observation and analysis of an information re-engineered supply chain: a case study of an automotive firm. Industrial Management \& Data Systems, 104 (8), 658-66.

Lipparini, A., \&Sobrero, M. (1994). The glue and the pieces: Entrepreneurship and innovation in small-firm networks. Journal of Business Venturing, 9(2), 125-140.

Man, T. W., Lau, T., \& Chan, K. F. (2002). The competitiveness of small and medium enterprises: a conceptualization with focus on entrepreneurial competencies. Journal of Business Venturing, 17(2), 123-142.

Man, W. Y. T. (2001). Entrepreneurial competencies and the performance of small and medium enterprises in the Hong Kong services sector (Doctoral dissertation, The Hong Kong Polytechnic University).

Murphy, G. B., Trailer, J. W., \& Hill, R. C. (1996).Measuring performance in entrepreneurship research. Journal of business research, 36(1), 15-23.

Markman, G.D., \& Baron.R.A. (1998). Social skills and entrepreneurs' financial success: Evidence that the ability to get along with others really matters. Paper presented at the Frontiers for Entrepreneurship Research.

Man, T. W., Lau, T., \& Snape, E. (2008). Entrepreneurial competencies and the performance of small and medium enterprises: an investigation through a framework of competitiveness. Journal of Small Business \& Entrepreneurship, 21(3), 257-276.

Mentzer, J. T. (2001). Supply chain management. United States of America: Sage Publications, Inc.

Meehan, J., \& Muir, L. (2008). SCM in Merseyside SMEs: Benefits and barriers. The TQM Journal, 20(3), 223-232.

Mudambi, R., Schrunder, C. P., \&Mongar, A. (2004). How co-operative is co-operative purchasing in smaller firms? Evidence from UK engineering SMEs.Long Range Planning, 37, 85-102.

Mitchelmore, S., \& Rowley, J. (2010). Entrepreneurial competencies: a literature review and development agenda. International Journal of Entrepreneurial Behaviour\& Research, 16(2), 92-111.

Martin, G., \&Staines, H. (1994).Managerial competences in small firms.Journal of Management Development, 13(7), $23-34$.

Mudambi, R., Schrunder, C. P., \&Mongar, A. (2004). How co-operative is co-operative purchasing in smaller firms? Evidence from UK engineering SMEs.Long Range Planning, 37, 85-102.

Morrissey, W. J., \&Pittaway, L. (2006). Buyer-Supplier Relationships in Small Firms The Use of Social Factors to Manage Relationships. International Small Business Journal, 24(3), 272-298.

Mole, V., Dawson, S., Winstanley, D. \&Sherval, J. (1993).Researching managerial competencies. Paper Presented to the British Academy of Management Annual Conference. Milton Keynes.

Nohria, N., \& Garcia-Pont, C. (1991).Global strategic linkages and industry structure. Strategic management journal, 12(1), 105-124.

Narasimhan, R., Kim, S.W., 2002. Effect of supply chain integration on the relationship between diversification and performance: 
evidence from Japanese and Korean firms. Journal of Operations Management 20 (3), 303-323.

Orme, G., \& Ashton, C. (2003).Ethics-a foundation competency. Industrial and Commercial Training, 35(5), 184-190.

Pfeffer, J., \&Salancik, G. (1978). The external control of organizations: A resource dependence perspective. New York: Harper and Row.

Perren, L. (2000). Factors in the growth of micro-enterprises (part2): exploring the implications. Journal of small business and enterprise development, 7(1), 58-68.

Park, D., \& Krishnan, H. A. (2001). Supplier selection practices among small firms in the United States: Testing three models. Journal of Small Business Management, 39(3), 259-271.

Radam, A., Abu, U. M. \&Abdullahn, A.M. (2008). Technical efficiency of SMEs in Malaysia: a stochastic frontier production model. International Journal of Economics and Management, 2(2), 395-408.

Rodrigues, A.M., Stank, T.P. and Lynch, D.F. (2004). Linking strategy, structure, process andperformance in integrated logistics.Journal of Business Logistics, 25(2), 65-94.

Richey Jr, R. G., Chen, H., Upreti, R., Fawcett, S. E., \& Adams, F. G. (2009).The moderating role of barriers on the relationship between drivers to supply chain integration and firm performance. International Journal of Physical Distribution \& Logistics Management, 39(10), 826-840.

Rasmussen, E., Mosey, S. and M. Wright. (2011). The Transformation of Network Ties to Develop Entrepreneurial Competencies for University Spin-off Emergence. Presented at the Academy of Management Conference, 12-16 August, San Antonio, Texas, USA.

Ragatz, G. L., Handfield, R. B., \& Peterson, K. J. (2002). Benefits associated with supplier integration into new product development under conditions of technology uncertainty. Journal of Business Research, 55, 389-400.

Sherer, P. D., \& Lee, K. (2002). Institutional change in large law firms: A resource dependency and institutional theory perspective. Academy of Management Journal, 45(1), 102-119.

Stead, W. E., Worrell, D. L., \& Stead, J. G. (1990).An integrative model for understanding and managing ethical behavior in business organizations. Journal of Business Ethics, 9(3), 233-242.

Salancik, G. R., \&Pfeffer, J. (1978).A social information processing approach to job attitudes and task design. Administrative science quarterly, 224-253.

Solesvik, M. (2012).Entrepreneurial competencies in emerging economy context.In 17th Nordic Conference on Small Business Research, Helsinki.-2012.-23-25 May.

Stevens, G.C., 1989. Integrating the supply chain.International Journal of PhysicalDistribution and Materials Management 19 (8), 3-8.

Stevens, G.C., 1990. Successful supply-chain management.Management Decision 28 (8), 25-30.

Stank, T. P., Keller, S. B., \&Closs, D. J. (2001). Performance benefits of supply chain logistical integration. Transportation Journal, $41(2 / 3), 32-46$.

Sherer, P. D., \& Lee, K. (2002). Institutional change in large law firms: A resource dependency and institutional perspective. Academy of Management Journal, 45(1), 102-119.

Stuart, R., \& Lindsay, P. (1997). Beyond the frame of management competencies: towards a contextually embedded framework of managerial competence in organizations. Journal of European Industrial Training, 21(1), 26-33.

Stank, T.P., Keller, S.B., Daugherty, P.J., 2001b. Supply chain collaboration and logistical service performance. Journal of Business Logistics 22 (1), 29-48.

Stokes, D., \& Blackburn, R. (2002).Learning the hard way: the lessons of owner-managers who have closed their businesses. Journal of Small Business and Enterprise Development, 9(1), 17-27.

Spence, L. J., \&Rutherfoord, R. (2003). Small business and empirical perspectives in business ethics: Editorial. Journal of Business Ethics, 47(1), 1-5.

Thakkar, J., Kanda, A., \&Deshmukh, S. G. (2009). Supply chain management for SMEs: A research introduction. Management Research News, 32(10), 970-993.

Thompson, J., \& Richardson, B. (1996). Strategic and competitive success: Towards a model of the comprehensively competent organization. Management Decision, 34(2), 5-19.

Tan, K.C., Kannan, V.R. and Handfield, R.B. (1998). Supply chain management: supplier performance and firm performance. International Journal of Purchasing and Materials Management, 34 (3), 2-9.

Thompson, J. E., Stuart, R., \& Lindsay, P. R. (1997). The competence of top team members: a framework for successful performance. Team performance management, 3(2), 57-75.

Wiklund, J. (1999). The sustainability of the entrepreneurial orientation-performance relationship. Entrepreneurship Theory and Practice, 24(1), 37-48.

Ward, A. (2004). Enterprise skills and enterprise learning. foresight, 6(2), 104-109.

Wijaya, Y. (2008). The prospect of familism in the global era: a study on the recent development of the ethnic-Chinese business, with particular attention to the Indonesian context. Journal of business ethics, 79(3), 311-317

Zairi, M., \& Peters, J. (2002).The impact of social responsibility on business performance. Managerial Auditing Journal, 17(4), 174-178.

Zhao, X., Huo, B., Selen, W., \& Yeung, J. H. Y. (2011).The impact of internal integration and relationship commitment on external integration. Journal of Operations Management, 29(1), 17-32.

Zhao, X., Huo, B., Flynn, B.B., Yeung, J., 2008.The impact of power and relationship commitment on the integration between manufacturers and customers in a supply chain. Journal of Operations Management 26 (3), 368-388.

Zahra, S., \& Nielsen, A. (1998).Integration as a moderator of the relationship between sources manufacturing capabilities and technology commercialization. In Academy of Management Meeting 1998, 7-12 August 1998. 